\title{
Numerical investigation into the effect of direct fuel injection on thermal stratification in HCCI engine
}

\begin{abstract}
Despite the fact that HCCI engines are distinguished by mixture homogeneity, some degree of stratification always appears inside a combustion chamber. It is especially applied to residual effect engines utilizing negative valve overlap. Mixture stratification is a result of the imperfect mixing of fresh air with trapped residuals. Direct fuel injection introduces stratification as well, due to fuel vaporization. As a consequence, the temperature within the combustion chamber is uneven. Thermal stratification affects auto-ignition timing and combustion evolution in a high extent. The purpose of this study was to evaluate a degree of thermal stratification in HCCI engine utilizing negative valve overlap. Investigations were performed using three-dimensional CFD model of the combustion system, made by using AVL FIRE software. Simulations were realized for various timings of fuel injection into the cylinder. It was found that fuel injection timing had a significant effect on the thermal stratification and resulting auto-ignition timing.
\end{abstract}

Key words: HCCI, direct injection, thermal stratification, CFD

\section{Introduction}

The problems of homogeneous charge compression ignition (HCCI) have been intensively investigated for last decades, as HCCI can be an interesting alternative to conventional spark ignition combustion. Because there is no flame propagation in the combustion chamber and fuel is highly diluted by air and re-circulated exhaust, low temperature combustion is obtained. It reduces $\mathrm{NO}_{\mathrm{x}}$ emissions even to $98 \%$ when compared to conventional spark ignition combustion [6]. Additionally low temperature, lack of throttling and fast heat release rate provide good fuel economy [7, 13]. Fuel consumption can be reduced by $11-16 \%$ when compared to modern spark ignition engines [9].

However, in HCCI engine, ignition is not initiated by spark plug thus there are difficulties with controlling the ignition timing and combustion speed [10]. As a result HCCI engines have a much higher rate of pressure rise than conventional engines, especially when chemical energy introduced with fuel is high. A large rate of pressure increase in the cylinder is the reason for limitation of HCCI operation range. Therefore, control of the combustion process is a crucial issue in development of this combustion system. It cannot be realized directly, via spark discharge, but few indirect methods can be utilized, i.e. internal exhaust gas recirculation $[1,5,11]$, valve timing control [8], stratification of the mixture and the temperature by controlling the injection strategy [2,3,11].The thermal stratification has a substantial impact on the combustion process. It affects the reaction rate of the combustible mixture. Thus, thermal stratification reduced heat release rate and pressure rise rate, enabling application of higher engine loads. Sjöberg et al. [12] found that a temperature difference even $30 \mathrm{~K}$ in the cylinder significantly influenced pressure release rate. These observations show that indirect combustion rate control can be achieved by thermal stratification. In engines using internal exhaust gas recirculation, some degree of thermal stratification appears due to the incomplete mixing of fresh air with gasses remaining after the previous cycle. Additional stratification can be achieved in direct injection engines due to thermal effects of fuel vaporisation.

This paper describes the investigations on the thermal effects of direct fuel injection and their impact on HCCI combustion. The experimental research was conducted on single cylinder engine. HCCI combustion was achieved with the use of negative valve overlap. Different split fuel injection techniques were compared. Combustion evolution was analysed on the basis of measured in-cylinder pressure. The observed trends were explained using 3D modelling of in-cylinder processes.

\section{Experimental setup and conditions}

The research engine is specified in Table 1. Engine was installed on a test bench equipped with a DC current dynamometer. The engine was equipped with a fully variable valve train with independent adjustment of valves lifts and timings. The valves lifts were adjusted with the hydraulic mechanism described in details in [4]. The fully variable valve train allowed to obtain internal EGR using the NVO technique. Valve timing and lift data are presented in Table 2.

The engine was operated at constant speed of 1500 $\mathrm{rev} / \mathrm{min}$. The pressure in the engine intake system was elevated to 1.5 bar absolute using a vane compressor. The total amount of fuel injected per cycle was $18 \mathrm{mg}$, which provided excess air ratio of 1.3. Engine load expressed by indicated mean effective pressure was approximately 0.5 MPa.

Fuel was injected into the cylinder with the use of single-stream swirl-type injector with fuel stream angle of approximately $70^{\circ}$. Analysed fuel injection strategies are shown in Fig. 1 and Table 3. In general half of the fuel was injected during NVO, whereas NVO fuel was split into two equal parts. The second half of fuel was injected during compression using different strategies, shown in Table 3, to achieve different degrees of stratification. 
Table 1. Technical specification of SB 3.5 research engine

\begin{tabular}{|l|c|}
\hline Displacement & $498.5 \mathrm{~cm}^{3}$ \\
\hline Bore/Stroke & $84 \mathrm{~mm} / 90 \mathrm{~mm}$ \\
\hline Compression ratio & 11.7 \\
\hline No. of valves & 2 \\
\hline Intake cam profile & $9.4 \mathrm{~mm}, 235^{\circ} \mathrm{CA}$ \\
\hline Exhaust cam profile & $9.2 \mathrm{~mm}, 235^{\circ} \mathrm{CA}$ \\
\hline Intake valve lift & $2.4-9.4 \mathrm{~mm}$ \\
\hline Exhaust valve lift & $2.2-9.2 \mathrm{~mm}$ \\
\hline Boost system & Electrically driven vane supercharger \\
\hline Fuel injector & Solenoid actuated swirl type \\
\hline Fuel pressure & $40-110$ bar \\
\hline Fuel & Gasoline $95 \mathrm{RON}$ \\
\hline
\end{tabular}

Table 2. Valve timings and lifts

\begin{tabular}{|l|c|}
\hline Intake valve opening /IVO & $82^{\circ} \mathrm{CA}$ \\
\hline Intake valve closing /IVC & $212^{\circ} \mathrm{CA}$ \\
\hline Intake valve lift & $3.6 \mathrm{~mm}$ \\
\hline Exhaust valve opening /EVO & $521^{\circ} \mathrm{CA}$ \\
\hline Exhaust valve closing /EVC & $640^{\circ} \mathrm{CA}$ \\
\hline Exhaust valve lift & $2.9 \mathrm{~mm}$ \\
\hline
\end{tabular}

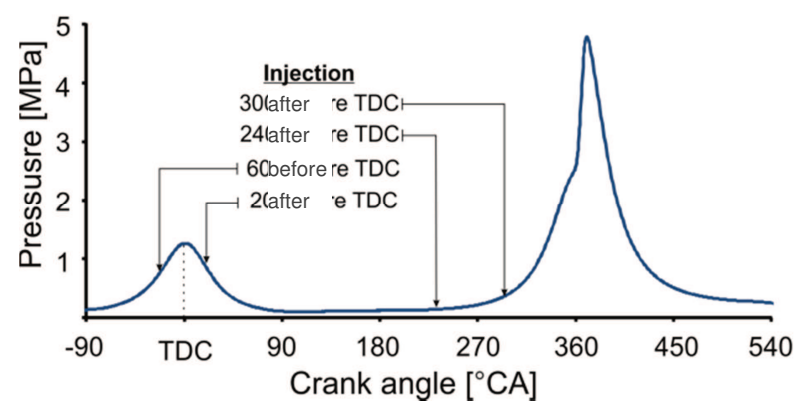

Fig. 1. Fuel injection strategy

Table 3. Fuel injection strategy and fuel quantities

\begin{tabular}{|c|c|c|c|c|}
\hline Case & $\begin{array}{c}60^{\circ} \mathrm{CA} \\
\text { bTDC }\end{array}$ & $\begin{array}{c}20^{\circ} \mathrm{CA} \\
\text { aTDC }\end{array}$ & $\begin{array}{c}240^{\circ} \mathrm{CA} \\
\text { aTDC }\end{array}$ & $\begin{array}{c}300^{\circ} \mathrm{CA} \\
\text { aTDC }\end{array}$ \\
\hline 1 & $4.5 \mathrm{mg}$ & $4.5 \mathrm{mg}$ & $4.5 \mathrm{mg}$ & $4.5 \mathrm{mg}$ \\
\hline 2 & $4.5 \mathrm{mg}$ & $4.5 \mathrm{mg}$ & $9.0 \mathrm{mg}$ & - \\
\hline 3 & $4.5 \mathrm{mg}$ & $4.5 \mathrm{mg}$ & - & $9.0 \mathrm{mg}$ \\
\hline
\end{tabular}

\section{Engine model}

In order to determine the influence of thermal stratification on the combustion process simulation software AVL FIRE was used. This is a specialized tool that uses numerical methods to solve fluid flow problems (CFD). The mathematical model geometry was the same as geometry of the experimental engine, shown in Table 1.

For computational purposes, a three-dimensional model of a test engine was prepared for which a mesh was constructed. Visualization of the resulting grid is shown in Fig. 2 . The mesh needed to calculate the combustion process was done using the FIRE FAME Hexa module, which is a supplementary part of the FIRE software. The standard method was used to create the mesh. This method involves striving for obtaining maximum number of cubic cells. The maximum cell size was set at $1 \mathrm{~mm}$. Temperature distributions were computed for the three injection cases investigated experimentally. They were utilized for analysis of the thermal effects of fuel injection.

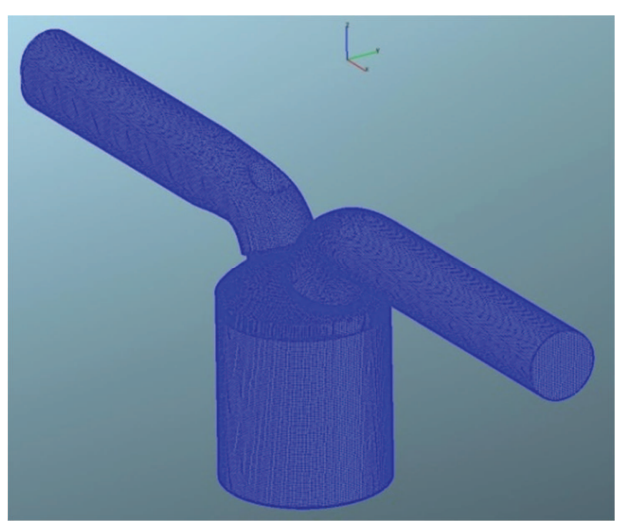

Fig. 2. Mesh model of the HCCI engine

\section{Results and discussion}

Experimental results are shown in Figs. 3 and 4. It can be noted that injection strategy indeed affects autoignition timing, however Fig. 4 shows that it does not affect peak HRR. It should be noted that ensemble averaged values presented in the traces are smoothed due to cycle-by-cycle variability. Actual values of combustion timing parameters and peak HRR, computed for each engine cycle separately are shown in Table 4.

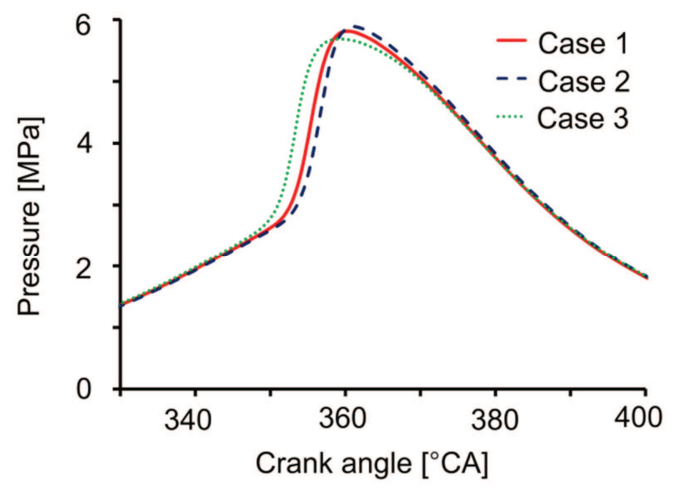

Fig. 3. Pressure in the cylinder for chosen cases (Table 4)

To illustrate thermal effects of each applied injection strategy, temperature distributions $10^{\circ} \mathrm{CA}$ after each injection are shown in Fig. 5. Temperature maps are shown for the plane in line with injection stream axis. The simulation results are presented for the Case 1 , where mass of fuel was equally distributed among four injection timings.

Table 4. Combustion parameters

\begin{tabular}{|c|c|c|c|}
\hline Case & $5 \% \mathrm{MFB}$ & $5-95 \% \mathrm{MFB}$ & Peak HRR \\
\hline 1 & $353.3^{\circ} \mathrm{CA}$ & $3.8^{\circ} \mathrm{CA}$ & $188 \mathrm{~J} /{ }^{\circ} \mathrm{CA}$ \\
\hline 2 & $354.4^{\circ} \mathrm{CA}$ & $3.9^{\circ} \mathrm{CA}$ & $200 \mathrm{~J} /{ }^{\circ} \mathrm{CA}$ \\
\hline 3 & $351.0^{\circ} \mathrm{CA}$ & $3.9^{\circ} \mathrm{CA}$ & $169 \mathrm{~J} /{ }^{\circ} \mathrm{CA}$ \\
\hline
\end{tabular}

Fig. 5 shows decrease of temperature after fuel injection before TDC in NVO period, whereas if fuel was injected 20 ${ }^{\circ} \mathrm{CA}$ after TDC there was no temperature traces $10{ }^{\circ} \mathrm{CA}$ after injection. It is plausible, because close to TDC the recompressed exhaust temperature was high, which enhanced vaporization, and additionally fluid velocity due to squish effect was higher, which enhanced mixing. Thus, the thermal effect of fuel injection disappeared quickly. 


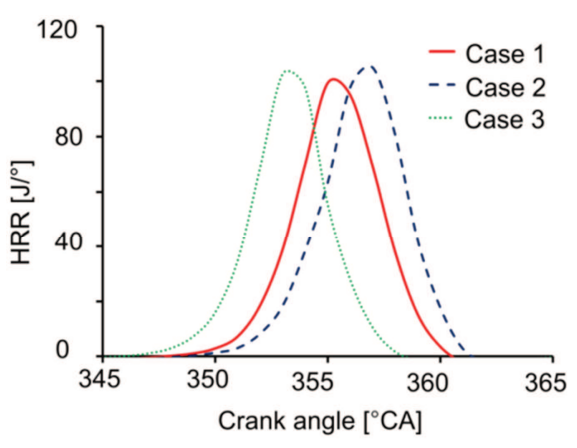

Fig. 4. Heat release rate for chosen cases (Table 4)

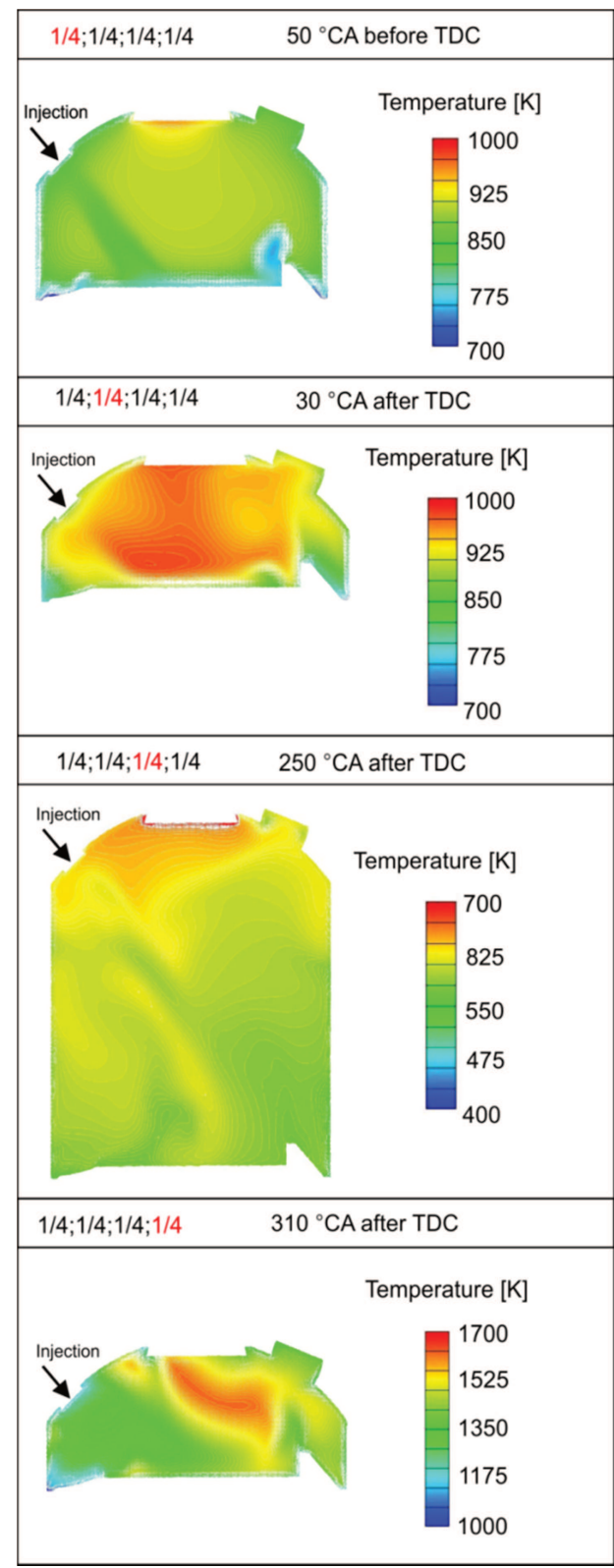

Fig. 5. Thermal stratification in the cylinder at different angles of injection

After fuel injection during the compression stroke thermal traces were clearly visible both for early and late injection, as shown in Fig. 5. It can be ascribed to longer vaporization process due to lower temperature. It should be noted that temperature fields in the bottom of the Fig. 5 indicate that exothermic reactions started. In fact, experimental results did not indicate any heat release at this timing. It is due to the fact that auto-ignition model was not validated properly, however, the present study is aimed at identification of temperature distribution before combustion rather that combustion process itself.

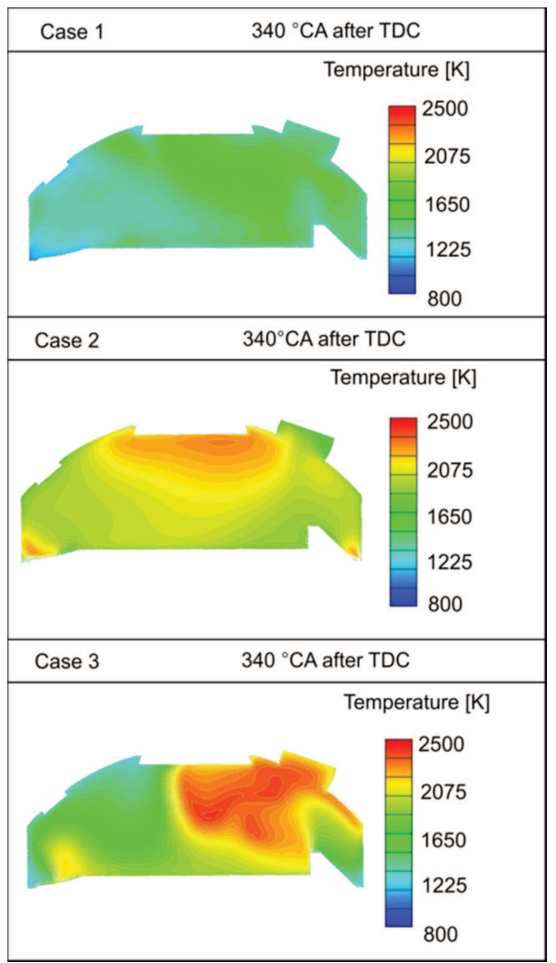

Fig. 6. Thermal stratification in the cylinder for $340{ }^{\circ} \mathrm{CA}$ after TDC

Figure 6 shows the in-cylinder temperature distribution at $340{ }^{\circ} \mathrm{CA}$ for all applied injection strategies. For Case 1 (even fuel distribution between two late injections) one can observe that temperature level is the lowest. However, it indicates that combustion process has already started. It can be also seen that the process is definirtelylow temperature combustion.

Among analysed cases experimental results provided the earliest start of injection for Case 3 and the latest for Case 2, as shown in Fig. 4. These results indicate that effects of fuel stratification and thermal stratification are not obvious. Experimental data show that the higher the stratification degree, the earlier the start of combustion. Despite the fact that in simulations combustion started to early, the observed trends can be explained by analysis of temperature maps in Fig. 5. In the Case 2, where injection was earlier lower stratification degree delayed start of combustion. In contrast, for Case 1 and Case 3 later injection provided higher stratification degree. As heat for fuel vaporisation was consumed locally, the temperature in the remaining volume was higher than average value. This region was the source of auto-ignition.

\section{Conclusions}

The effects of thermal stratification on auto-ignition timing and combustion in a gasoline fuelled HCCI engine were investigated. To provide insight into spatial temperature distribution in combustion chamber experimental results were complemented by 3D simulations. 
Obtained experimental results showed that under investigated conditions higher amount of fuel injected later resulted in earlier start of combustion. Analysis of temperature distribution maps obtained from 3D modelling of the engine processes revealed that the more fuel was injected the later, the larger temperature span was observed. Larger thermal stratification resulted in appearance high temperature spots, which were the sources of auto-ignition.

It should be noted, however, that applied auto-ignition and combustion model was not properly validated for $\mathrm{HCCI}$ processes. Nevertheless modelling enabled analysis of the thermal effects of direct fuel injection locally and explained experimental results.

\section{Acknowledgements}

The research was funded by the National Science Centre, Poland, grant No. 2015/17/B/ST8/03279. The authors wish to thank AVL List GmbH for making simulation software available within a framework of AVL University Partnership Program.

\section{Nomenclature}

aTDC after top dead centre

bTDC before top dead centre

CA crank angle

CFD computational fluid dynamics

EGR exhaust gas recirculation
HCCI homogeneous charge compression ignition

HRR heat release rate

MFB mass fraction burnt

NVO negative valve overlap

TDC top dead centre

\section{Bibliography}

[1] ALEIFERIS, P., CHARALAMBIDES, A., HARDALUPAS, Y. et al. Modelling and experiments of HCCI engine combustion with charge stratification and internal EGR. SAE Technical Paper. 2005, 2005-01-3725.

[2] GUOHONG, T., ZHI, W., JIANXIN, W. et al. HCCI combustion control by injection strategy with negative valve overlap in a GDI engine. SAE Technical Paper. 2006, 2006-01.0415.

[3] HUNICZ, J., GĘCA M., KORDOS P. An experimental study of boosted gasoline HCCI engine under different direct fuel injection strategies. Experimental Thermal and Fluid Science. 2015, 4.

[4] HUNICZ, J., KORDOS, P. Experimental study of the gasoline engine operated in spark ignition and controlled auto-ignition combustion modes. SAE Technical Paper. 2009, 2009-01-2667.

[5] KAWASAKI, K., HIROTA, K., NAGATA, S. et al. Improvement of natural-gas HCCI combustion by internal EGR by means of exhaust valve re-opening. SAE Int. J. Engines. 2010, 2(2), 733-739.

[6] MASE, Y., KAWASHIMA, J., SATO, T., EGUCHI, M. Nissan's new multivalve DI diesel engine series. SAE Technical Paper. 1998, 981039.

[7] NAJT, P., FOSTER, D.E. Compression-ignited homogeneous charge combustion. SAE Technical Paper. $1983,830264$.
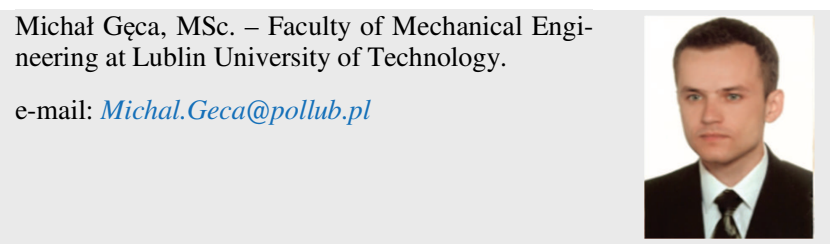

Piotr Jaworski, MSc. - Division of Aircraft Engines at Warsaw University of Technology. e-mail: Piotr.Jaworski@itc.pw.edu.pl
[8] OGURA, M., SASAKI, T., KAWAGUCHI, Y. HCCI combustion control by intake and exhaust continuous variable valve timing mechanism in premixed gasoline engine. SAE Technical Paper. 2004, 2004-32-0096.

[9] PULKRABEK, W.W. Engineering fundamental of the internal combustion engine 2nd edition. Pearson Prentice-Hall. Upper Saddle River, NJ, 2004.

[10] SJÖBERG M., DEC, J.E. Comparing late-cycle autoignition stability for single- and two-stage ignition fuels in HCCI engines. Proceedings of the Combustion Institute. 2007, 31, 2895-2902.

[11] SJÖBERG, M., DEC, J., HWANG, W. Thermodynamic and chemical effects of EGR and its constituents on HCCI autoignition. SAE Technical Paper. 2007, 2007-01-0207.

[12] SJÖBERG, M., DEC, J.E., CERNANSKY, N. Potential of thermal stratification and combustion retard for reducing pressure-rise rates in HCCI engines, based on multi-zone modeling and experiments. SAE Technical Paper. 2005, 2005-01-0113.

[13] STANGLMAIER, R.H., ROBERTS, C.E. Homogeneous charge compression ignition (HCCI): benefits, compromises, and future engine applications. SAE Technical Paper. 1999, 1999-01-3682.

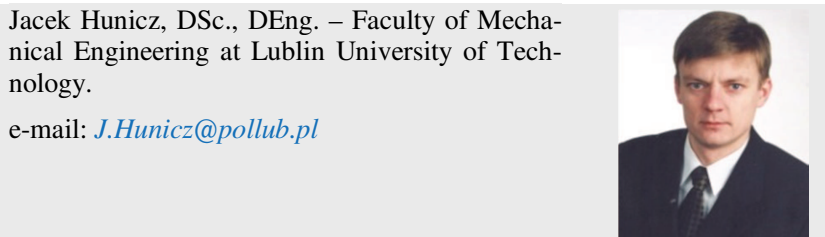

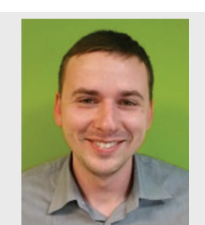

